\title{
CONCERNING THE PROBLEM OF IDENTIFYING THE SCYTHIAN CENTERS OF POWER IN EASTERN EUROPE IN THE VII-VI centuries BC
}

The analysis of the Scythian burials of the $7^{\text {th }}$ $6^{\text {th }}$ centuries BC in the south of Eastern Europe, allowed the author to identify several groups of monuments located in the North Caucasus and Ukrainian forest-steppe: Central Ciscaucasian, Kuban, PosulskoVorsklinskaya and Kyiv-Cherkasskaya. The clusters of kurgans associated with these groups include burials of the Scythian military elite together with large "royal" tumuli.

Keywords: Scythians, centers of power, $7^{\text {th }}-6^{\text {th }}$ centuries BC, North Caucasus, Ukrainian forest-steppe.

Introduction. In the south of Eastern Europe, the $7^{\text {th }}-6^{\text {th }}$ centuries $\mathrm{BC}$ are associated with the emergence and activity of the Scythians. These nomads were directly involved in the most important events of the world history, coming into contact with such leading powers of Western Asia as Urartu, Assyria, Media, as well as Greek city-states of the Black Sea coastal area. At the same time, the structure of the early Scythian tribal community remains poorly studied. Written sources report that in the $7^{\text {th }}$ century BC the Scythians had tribal chiefs (for example, Ishpakai), king Bartatua and own territory (Iskuza country; Хазанов 1975 , с. 218). The benefit for the king of Assyria from the marriage of his daughter with the king of the Scythians and transfer of power to Madys, the son of Bartatua, testifies to the hereditary character of the royal power of the Scythians. Based on the data from medieval sources, one can speak of various functions that rulers of nomads performed (supreme commander, judge and administrator, resource manager, carrier of sacral functions, etc.), which demonstrates the complex nature of power with several levels of its manifestation: mythologi- cal, generic, state and historical (Васютин 2015; Трепалов 2004). On the other hand, performance of these functions implies existence of centers of their concentration in the habitats of the Scythians. These habitats are fixed for the $7^{\text {th }}-6^{\text {th }}$ centuries BC based on the concentration of Scythian funeral sites. For this time, the main regions of their distribution are the North Caucasus (about 80 graves) and the forest-steppe Dnieper region (on the left bank of the Dnieper - more than 150 burials, and on the right one - 177). Given the militarized nature of the Scythian society and the existence of "tsars", it can be assumed that the centers of power should mark, first of all, the concentration of elite military graves and the presence of large "royal» kurgans. For the early Scythians, the clan-tribal nature of their community is also undoubted, which, in turn, is reflected in the specifics of the funeral rites available for archaeological analysis proposed in this article.

North Caucasus. In the North Caucasus, there are two main areas of concentration of the early Scythian monuments: the Central Ciscaucasus and the basin of the middle Kuban. They are represented mainly by kurgan-type burial mounds (Krasnoe Znamia, Novozavedennoye II, Nartan, Kelermes, etc.) (Батчаев 1985; Махортых 1991; Галанина 1997; Петренко 2006). A characteristic feature of the Scythian burials of Stavropol area and the neighboring Kabardino-Balkaria is their primary position in specially constructed kurgans, while in the North-West Caucasus Scythian graves are known to be secondary to the Bronze Age barrows, or "dumped in» on top of them (for example, Kostromskoy kurgan, Kelermes, kurgan 19, burial 5, etc.). Tumuli, especially in the territory of the Central Ciscaucasia, 
often had stone facing of the mantel or were lined with a layer of cobblestone.

Scythian burials of the $7^{\text {th }}-6^{\text {th }}$ centuries BC in the North Caucasus were made at the level of the ancient horizon (at least 20) and in ground pits (about 60).

At the buried soil level, several types of burial structures stand out, among which burials in stone and wooden tombs are dominant. Such funerary constructions were sometimes overlapped by $11-15$ meters high kurgans, which belong to the category of «royal» ones (kurgan 1 Krasnoe Znamia, kurgan 1/1898 Ulsky necropolis).

The main area of above-ground stone tombs distribution, which have a square and more rarely rectangular form, is the Central Ciscaucasia (kurgans 1, 4, 8 Krasnoe Znamia; 1924 and 1984 near the city of Stavropol), while in the Kuban area they are sporadic (kurgan 41 of the Klady cemetery) (Лесков, Эрлих 1999, рис. 39; Петренко 2006, c. 49). Their sizes vary from $2.7 \times$ $2.3 \mathrm{~m}$ to $10.8 \times 10.3 \mathrm{~m}$. Tombs orientation is usually unstable: latitudinal or angles to the cardinal points. Burned grave structures as well as presence of ceilings supported by retaining pillars in the center or at the corners are typical for this type of burial constructions. Some tombs have entrances - dromoses, leading into the chamber from the west or south. The main period of existence of ground stone tombs covered by kurgans coincide with the $7^{\text {th }}$ century BC.

Above-ground wooden tombs under barrows concentrate on the left bank of the middle Kuban river ${ }^{1}$. In addition to the Kostromskoy kurgan, most of these structures are associated with the Ulsky necropolis, which was mainly excavated in the late $19^{\text {th }}$ - early $20^{\text {th }}$ centuries, unfortunately, with no satisfactory fixation of the details of the funeral rite. According to extant information, wooden tombs of rectangular $(7.45 \times 5.7 \mathrm{~m})$ and square $(5 \times 5 \mathrm{~m})$ shapes were opened in the 1/1898 and 1/1909 kurgans, at four corner pillars, where numerous horse skeletons were located into the west and east off these tombs (Отчет... 1898, с. 30, рис. $42 ; 1909$ и 1910, с. 147; Ульские... 2015).

More reliable information was obtained as a result of the excavations of the $10^{\text {th }}$ Ulsky kurgan by A. M. Leskov in 1982 (Сокровища... 1985). An earthen platform was opened under the mound, the top of which had the appearance of a flat ground with a diameter of $20 \mathrm{~m}$ with gentle sloping ramp on the south side. There was a wooden tomb in the center of the construction with a ritual area inside. There were remains of twen-

1. It is necessary to mention the burials found on the same territory, made at the level of the ancient surface without any signs of wooden or stone constructions, but with horse sacrifices and / or mournful offerings in the form of ceramics, etc. (kurgans - the 10th Razmennyi; the 1st Goverdovsky, 23/1986 and 29/1988 Kelermes (Галанина 1997; Эрлих, Нехаев 2011; Рябкова 2014). ty-nine horse skeletons around it, covered with a wooden canopy. Similar ground structure was also traced in one of the Ulsky tumulus (supposedly, kurgan 2/1909) excavated by V. R. Erlikh in 2007 (Эрлих 2010).

It is worth to mention the recent reinvestigation of the famous Kostromskoy kurgan, which resulted in establishing that it was erected above a kurgan of the Bronze Age, on a specially prepared under-kurgan ground in the form of an extended circle of $26 \times 24 \times 0.8 \mathrm{~m}$ size with a flat top. There was a tomb of logs on the surface of the ground in three or four row of beams. A wooden frame was a bearer of the tomb. Stubs hammered into the surface of the ground and fixed from the inside of the frame served as the reinforcement of the walls of this structure (Рябкова 2014).

In the pre-Scythian and Scythian time, burials at the level of the ancient horizon were also spread on the right bank of the middle Dnieper region (Ильинская 1975, с. 83; Ковпаненко 1981; Maхортых 1991). The following features bring them closer to those of the North Caucasus: destroying by fire or burning of the burial structure; the entrance to the tomb is often from the south; the presence of lateral and central pole holes from pillars supporting the ceiling; use of stone and wood for the construction of funeral structures.

The most numerous variety of the Scythian grave constructions of the $7^{\text {th }}-6^{\text {th }}$ centuries BC in the North Caucasus are burials in ground pits. The following types of such burials are distinguished: 1) in simple ground pits; 2) in wooden pillar tombs; 3) in wooden log «cabins»; 4) in a stone tomb lowered into a ground pit with a wooden ceiling; 5) in a tomb combining wooden and stone structures in the walls and ceilings (Maхортых 1991). The first three types of burials (Krasnoe Znamia, Novozavedennoye II, Nartan and Kelermes cemeteries) are the most common, while the burials in pits with stone structures inside are occasional (Krasnoe Znamia, kurgans 2, 7).

To ceil a grave pits, wood and reed as well as stone covering from several layers of cobblestone were used, often leaning on longitudinal beams supported from the inside of the grave by pillars. It is necessary to note the presence of overa-grave constructions consisting of a ritual reed platform round the grave, a throw ring covered with stone or reed, as well as traces of rituals and funeral feasts (hearths, coals, bits and pieces of vessels, animal bones), are found accumulated in mounds and in fillings of ditches (Петренко, Маслов, Канторович 2009).

Burials were committed in the sub-square $(2.8 \times 2.8 \mathrm{~m}-6 \times 6 \mathrm{~m})$ and rectangular $(2.8 \times$ $2.4 \mathrm{~m}-8.5 \times 6.5 \mathrm{~m})$ pits with various orientations: with respect to latitude, along the northwest, southeast line; with respect to angles to the cardinal points, etc. 
Because of the general robberies of graves, information about the posture and orientation of the dead is scarce. One can speak of the predominance of the extended position of skeletons headed to the south and, more rarely, to the west, sometimes with deviations (Krasnoe Znamia; Novozavedennoye II, Novopavlovsk, Kelermes).

An interesting specificity of the ritual is placing of stele-shaped stones over the graves of the most notable dead, the presence of stone slabs and less often altars as well as heaps of pebbles in burial grounds.

Among the characteristic features of the burial rite of the Scythian sites of the North Caucasus, there are numerous horse burials laid in the same grave as the buried, or outside the burial chamber, along its walls, emphasizing the special importance of the role of cavalry warriors. It is noteworthy that in the forest-steppe Dnieper region it was practiced to replace horse sacrifices by placing a large number of horse bridles in the graves.

The local peculiarities of some North Caucasian burial grounds are manifested in the original arrangement of the bottom of the grave pits, where the eastern part is allocated for burial places for humans, and the western part raised to the east by $20-25 \mathrm{~cm}$ and used to bury horses (Krasnoe Znamia); in laying the dead on the bedding of wooden cross-bars or on organic spreading (Novozavedennoye II) (Петренко 2006). Design features are different in some of the Nartan graves. Thus, there are special "hangers» arranged in kurgan 11, and the chamber had oval corner ledges in kurgan 19.

Thus, in the North Caucasus, two main groups of funerary sites are fixed, the first of which is localized in the Kuban region, and the second in the Central Ciscaucasia. Their coexistence shows the complex composition of the tribal community that lived on north side of the Great Caucasus range. Presence of the Scythians in this region was associated not only with the Near Eastern military campaigns, but also with their subsequent residence here in the $6^{\text {th }}$ century BC, as evidenced by the materials of the cemeteries Novozavedennoye II, Nartan, etc. This circumstance, along with the spread of Scythian monuments in the forest-steppe Dnieper region in the $7^{\text {th }}$ century BC (for example, Medvin 2, Teklino 346, Zhabotin 524, etc.), allows correcting the point of view about the movement of the center of Scythia from Ciscaucasia to the steppes of the Northern Black Sea coast in the $6^{\text {th }}$ century BC (Мурзин 1984). In my opinion, it is more correct to talk about existence of several Scythian centers of power in the south of Eastern Europe in the archaic epoch, which could function in parallel with each other.

Forest-steppe Dnieper region. There are two main areas of the Scythian antiquities of the $7^{\text {th }}$ $6^{\text {th }}$ centuries BC concentration in the Ukrainian forest-steppe: the Kyiv-Cherkasskaya one on the right bank and the Posulsko-Vorsklinskaya one on the left bank of the Dnieper. In the right-bank Ukraine, most of the monuments are located in Porosye (68 graves) and the Tiasmyn river basin (109 graves); on the left bank - in the basins of the Sula river (80 graves) and the Vorskla river (97 graves) (Ковпаненко 1967; Ильинская 1968; Ковпаненко, Бессонова, Скорый 1989; Махортых 2013).

Despite the fact that the Kyiv Dnieper region is the most northern and sparse distribution area of the Scythian antiquities, this is where the largest kurgans of the archaic period of the Dnieper forest-steppe right bank are concentrated: Glevakha $(8.7 \mathrm{~m})$, Perepyatykha $(11 \mathrm{~m})$, etc. Even more grandiose «royal» kurgans of the early Scythian period were discovered on the territory of the forest-steppe left bank of the Dnieper, where they are concentrated mainly in the Posulye area near the villages of Aksyutintsy and Volkovtsy. The height of their mounds ranges from $7-8.5 \mathrm{~m}$ (kurgans 10, 11, 14 in the Staykin Verkh tract) up to 19-20 m (Starshaya Mohyla, Shumeiko). Both in Kyiv region and in Posulye, the abovementioned elite "cemeteries» are brought together by a similar location in peripheral areas hard-to-get and remote from the steppe Black Sea coast in the northern part of the forest-steppe Dnieper region. In this case, a connection can be traced between the archaeological materials and the surviving written evidence of Herodotus (IV, 127) about the father's graves safely sheltered from enemies and protected by the Scythians, with which, in my opinion, the above-mentioned early Scythian tribal tombs of the nomadic forest-steppe Ukraine nobility should be associated (Maхортых 2012).

Among the grave constructions under kurgans in the Dnieper forest-steppe right bank and left bank regions burials in the pits dominate, constituting, respectively, $87 \%$ and $99 \%$ of the total number of fixed burial structures of the $7^{\text {th }}$ $6^{\text {th }}$ centuries BC. They are mainly represented by burials in simple ground pits (64\% of the right bank and $59 \%$ of the left bank) and in pits with wooden structures inside (32\% of the right bank and $38 \%$ of the left bank). Judging by the available data, the north-south orientation of grave pits (18\%) prevails in Porosye on the right bank of the Dnieper, and latitudinal (21\%) predominates on the Tiasmyn river.

The peculiarity of the internal space of burial chambers of the Porosye barrows (Bobrytsa kurgan 40, Stepantsy kurgan 11, etc.) is the presence of an internal partition dividing them into two compartments (Ковпаненко 1981). A series of pillars (Glevakha, Flyarkovka and other tumuli of the forest-steppe right bank region), dividing the grave into separate sections and located along the walls and/or in the central part of the tomb, could similarly perform such a «demarcation» function (besides a support for the ceiling). On 
the left bank of the Dnieper, similar structures have not yet been identified.

To the west of the Dnieper, wooden structures in the mounds and pits were quite often set on fire with a ceremonial purpose, whereas, in the left bank region, this tradition was not widespread. At the same time, a different custom is distinctly expressed in the basins of the Sula and the Vorskla rivers which is strewing the bottom of the grave with lime, ashes and other symbols of fire (Ильинская 1968).

Turning to the orientation of the deceased, it is necessary to point out that on the right bank it is rather unstable. Despite the diversity, both in Porosye and at the Tiasmyn river the western orientation of the buried (24-33\%) is dominating, and the second place is occupied by the southern (14-19\%) one. The northern (14\%) and eastern orientations of the skeletons (10\%) are quite representative (Ковпаненко, Бессонова, Скорый 1989).

The peculiarity of the Dnieper forest-steppe right bank region is also manifested in the widespread cremation rite, which was recorded in 71 cases, making more than $36 \%$ of the total number of burials. The left bank Scythian burials look uniform with a predominance of the southern orientation and inhumation rite (Махортых 2012).

It can be assumed that during and after the end of the period of nomadic invasions to the Near East into the forest-steppe regions of the Dnieper region, several Scythian tribal or clan groups migrated. On the left bank, one of these groups center was located in the Sula river basin, where a steady tradition of construction magnificent «royal» tumuli had established, which continued to exist even later, in the $5^{\text {th }}-4^{\text {th }}$ centuries BC (kurgan 2 Aksyutintsy - $10.6 \mathrm{~m}$, kurgan 1 (1897) Volkovtsy - $13.5 \mathrm{~m}$, etc.). Their monumentalism presupposed the use of labor of a significant number of people, which indicates the large number of the members of this group. It retained historical continuity and power over the next few centuries.

A somewhat different picture emerges from the materials of the archaic Scythian sites of the right bank forest-steppe, where several clan groups migrated with the western, northern and eastern orientations of the dead. The lesser consolidation of their members did not allow them to create an analogue of the Posulye center with extensive burial grounds and gigantic "royal» kurgans, reflecting the complex internal hierarchy of the society. The same reason could have caused a significant amount of secondary burials to the kurgans of the Bronze Age, in contrast to the left bank forest-steppe, where human resources allowed to create new tumuli for their dead. However, probably due to its relative internal small size, the Scythian groups of the right bank region maintained close, first of all, marriage contacts with the local sedentary population, which found reflection in the spread of a cremation rite. Its origins in the Middle Dnieper region date back to the epoch of copper and bronze (Ильинская 1975, c. 78; Скорий 1990). As an influence of the Cimmerian predecessors, one can consider burials at the level of the ancient horizon, tent and some other funeral constructions known in the Dnieper right bank region in the pre-Scythian and early Scythian time (Mахортых 2012).

Single large kurgans, known on the right bank in the Kyiv Dnieper region, can be considered as burial places of the ruling top of local tribal groups, which, unlike in the Posulye center, functioned for a relatively short period of time during the late $7^{\text {th }}$ and / or early $6^{\text {th }}$ centuries BC.

Conclusions. The above mentioned data indicate that in the south of Eastern Europe in the $7^{\text {th }}-6^{\text {th }}$ centuries BC there were several centers of power, one of the most reliable and informative archaeological markers of which are the Scythian funerary monuments, and in particular burial grounds.

Common features of the Scythian funerary monuments of the $7^{\text {th }}-6^{\text {th }}$ centuries $\mathrm{BC}$ are the following:

- domination of the kurgan burial rite;

- construction of the barrow, mainly for one burial with rare cases of secondary burials;

- construction of «royal» kurgans up to 8-20 m high;

- prevalence of simple ground pits and wooden pillar tombs among burial structures;

- a significant spread of funeral feasts and a ritual use of fire;

- domination of the extended inhumation on the back with the few cases of the crouched position of the dead.

- predominance of the burials of male warriors.

Regional specificity is manifested in the following:

- interments under specially constructed mounds are more characteristic for the Central Ciscaucasia and the Dnieper left bank region, while Scythian secondary burials in the kurgans of the Bronze Age were more widely spread in the Kuban and the Dnieper right bank regions;

- the main concentration of burials made at the level of the ancient horizon is recorded in the North Caucasus and the Middle Dnieper area;

- division of the burial chamber space into a number of sectors is fixed in the Central Ciscaucasia (with the help of ground ledges) and in the Dnieper right bank region (by wooden partitions);

- for the forest-steppe Dnieper left bank area, there is a characteristic arrangement of wooden flooring at the bottom of the grave pits, supported on bars, laid in specially dug grooves (logs);

- large number of horse burials in the Scythian monuments of the North Caucasus, which in the 
forest-steppe Dnieper region were substituted by placing horse bridles into a grave;

- in the North Caucasus and in the foreststeppe Dnieper right bank region, wooden constructions in the kurgans were set on fire with a ceremonial purpose, whereas the tradition of powdering the bottom of pits with ash, lime and red paint spread on the left bank area;

- the use of cremation in the Central Ciscaucasia and on the right bank of the Dnieper, not characteristic of the left bank region;

- southern and those close to it (southwestern or southeastern) orientations of the deceased are typical mainly for the forest-steppe Dnieper left bank and, judging by the few data, for the North Caucasus, while the western one dominates on the right bank, where eastern and northern orientations also quite common.

The above proposed features of the Scythian monuments of the $7^{\text {th }}-6^{\text {th }}$ centuries BC in the south of Eastern Europe, the list of which can be continued, testifies to the heterogeneity of the Scythian nomadic communities localized here. There are several peculiar groups of monuments - Central Ciscaucasian, Kuban, Posulsko-Vorsklinskaya and Kyiv-Cherkasskaya. The first two can be considered in the framework of the North Caucasian center of power that existed during the $7^{\text {th }}-6^{\text {th }}$ centuries BC. In the Dnieper region, two such centers can be identified. The first of them, in the forest-steppe right bank, apparently belonged to several heterogeneous tribal groups and ended its existence in the second half of the $6^{\text {th }}$ century BC. The second center, in the forest-steppe left bank area, was associated with a homogeneous and numerous groups of the Scythian people who had lived there from the $7^{\text {th }}-6^{\text {th }}$ centuries BC up to $4^{\text {th }}$ century BC.

The tribal diversity, combined with the distinguishing «centers of power» marked by clusters of kurgans with the burials of the Scythian military aristocracy, determine the ethno-cultural specifics of various regions of the south of Eastern Europe in the $7^{\text {th }}$ and $6^{\text {th }}$ centuries BC. New studies will make it possible to specify the question of the principles on which the administrative-territorial division of the Eastern European Scythia was based in the $7^{\text {th }}-6^{\text {th }}$ centuries BC, as well as to trace the further historical fate of the Scythian tribal formations localized there.

\section{ЛІТЕРАТУРА}

Батчаев, В. М. 1985. Древности предскифрского и скифского периодов. Археологические исследования на новостройках Кабардино-Балкарии, II, с. 7-115.

Васютин, С. А. 2015. Традиционные и инновационые механизмы управления в кочевых обществах Центральной Азии VI-XIII вв. Вестник Келеровского университета, 1 (61), с. 13-19.

Галанина, Л. К. 1997. Келерлесские курганьь. "Царские» погребения раннескифбкой эпохи. Москва: Палеграфр.
Ильинская, В. А. 1975. Раннескибские кургань бассейна р. Тяслин. Киев: Наукова думка.

Ильинская, В. А. 1968. Скифбы Днепровского лесостепного Левобережья. Киев: Наукова думка.

Ковпаненко, Г. Т. 1967. Племена скіфбського часу на Ворсклі. Київ: Наукова думка.

Ковпаненко, Г. Т. 1981. Курганы раннескифбского времени в бассейне р. Рось. Киев: Нукова думка.

Ковпаненко, Г. Т., Бессонова, С. С., Скорый, С. А. 1989. Памятники скифбской эпохи Днепровского лесостепного Правобережья. Киев: Наукова думка.

Лесков, А. М., Эрлих, В. Р. 1999. Могильник Фарс. Клады. Москва: Государственный музей Востока.

Махортых, С. В. 1991. Скифбы на Севернол Кавказе. Киев: Наукова думка.

Махортых, С. В. 2012. Общее и особенное в погребальной обрядности ранних скифов лесостепной Украины. В: Разуваев, Ю. Д. (ред.). Восточноевропейские древности. Воронеж: Научная книга, с. 106-118.

Махортых, С. В. 2013. Погребальные сооружения и обряд курганных некрополей Бельского городища. Stratum plus, 3, c. 223-256.

Мурзин, В. Ю. 1984. Скифбская архаика Северного Причернолорья. Киев: Наукова думка.

Отчет... 1901. Отчет археологической колиссии за 1898 г. Санкт-Петербург: Главное управление уделов.

Отчет... 1903. Отчет археологической колиссии за 1909 и 1910 гг. Санкт-Петербург: Главное управление уделов.

Петренко, В. Г. 2006. Краснозналенский могильник. Элитные курганы раннескифской эпохи на Севернол Кавказе. Москва: Палеграф.

Петренко, В. Г., Маслов, В. Е., Канторович, А. Р. 2009. Некоторые итоги исследования раннескифрского могильника Новозаведенное-II в 1991-2003 гг. Аpxeологические открытия 1991-2004 г2., с. 225-234.

Рябкова, Т. В. 2014. Южно-Кубанская и предшествующие археологические экспедиции. В: Пиотровский, М. Б. (ред.). Экспедиции. Археология в Эрлитаже. Санкт-Петербург: Славия, с. 236-249.

Скорий, С. А. 1990. Курган Перепятиха. Киев: Наукова думка.

Сокровища... 1985. Сокровища курганов Адыгеи. Москва: Советский художник.

Ульские... 2015. Ульские курганьь. Культово-погребальный колплекс скифского врелени на Севернол Кавказе. Москва: Палеграфр.

Трепавлов, В. В. 2004. Вождь и жрец в эпическом фольклоре тюрко-монгольских народов: некоторые особенности организации традиционной власти у кочевников. В: Базаров, Б. В., Крадин, К. К. (ред.). Монгольская илперия и кочевой мир. Улан-Удэ: БНЦ СО РАН, с. 76-100.

Хазанов, А. М. 1975. Социальная история скиббов. Москва: Наука.

Эрлих, В. Р. 2010. Раскопки кургана Ульской группы в 2007 г. Материальная культура Востока, 5, c. $117-137$.

Эрлих, В. Р, Нехаев, А. А. 2011. Курганы эпохи скифской архаики у хутора Говердовский в Адыгее. В: Мамаев, Х. М. (ред.). Вопросы древней и средневековой археологии Кавказа. Грозный; Москва: ИА PAH, c. 131-152.

\section{REFERENCES}

Batchaev, V. M. 1985. Drevnosti predskifskogo i skifskogo periodov. Arkheologicheskie issledovanija na novostrojkakh Kabardino-Balkarii, II, s. 7-115. 
Vasiutin, S. A. 2015. Traditsionnye I innovatsionye mekhanizmy upravleniya $\mathrm{v}$ kochevykh obschestvakh Tsentralnoy Azii VI-XIII vv. Vestnik Kemerovskogo universiteta, 1 (61), s. 13-19.

Galanina, L. K. 1997. Kelermesskie kurgany. "Tsarskie» pogrebeniya ranneskiskoj epokhi. Moskva: Palegraf.

Il'inskaya, V.A. 1975. Ranneskifskie kurgany bassejna r. Tyas'min. Kiev: Naukova dumka.

Il'inskaya, V. A. 1968. Skify Dneprovskogo lesostepnogo Levoberezh'ya. Kyiv: Naukova dumka.

Kovpanenko, G. T. 1967. Plemena skifskogo chasy na Vorskli. Kyiv: Naukova dumka.

Kovpanenko, G. T. 1981. Kurgany ranneskifskogo chasy $v$ bassejne r. Ros'. Kyiv: Naukova dumka.

Kovpanenko, G. T., Bessonova, S. S., Skoriy, S. A. 1989. Pamyatniki skifskoy epokhi Dneprovskogo Lesostepnogo Pravoberezhia. Kyiv: Naukova dumka.

Leskov, A. M., Erlikh, V. R. 1999. Mogilnik Fars. Klady. Moskva: Gosudarstnenniy muzej vostoka.

Makhortykh, S. V. 1991. Skify na Severnom Kavkaze. Kiev: Naukova dumka.

Makhortykh, S. V. 2012. Obschee i osobennoe v pogrebalnoj obryadnosti rannikh skifov lesostepnoj Ukrainy. In: Razuvaev, Yu. D. (ed.). Vostochnoevropejskie drevnosti. Voronezh: Nauchnaya kniga, s. 106-118.

Makhortykh, S. V. 2014. Pogrebalnye sooruzheniya i obryad kurgannykh nekropolej Belskogo gorodischa. Stratum plus, 3, s. 223-256.

Murzin, V.Yu. 1984. Skifskaya archaika Severnogo Prichernomorya. Kiev: Naukova dumka.

Otchet... 1901. Otchet arkheologicheskoy komissii za $1898 \mathrm{~g}$. Sankt-Peterburg: Tipographiya glavnogo upravleniya udelov.

Otchet... 1913. Otchet arkheologicheskoy komissii za 1909 i 1910 gg. Sankt-Peterburg: Tipographiya glavnogo upravleniya udelov.

Petrenko, V. G. 2006. Krasnoznamenskiy mogilnik. Elitnye kurgany ranneskifskoj epokhi na Severnom Kavkaze. Moskva: Palegraf.

Petrenko, V. G., Maslov, V. E., Kantorovich, A. R. 2009. Nekotorye itogi issledovaniya ranneskifskogo mogilnika Novozavedennoe-II v 1991-2003 gg. Archeologicheskie otkrytiya 1991-2004 gg., s. 225-234.

Ryabkova, T. V. 2014. Yuzno-Kubanskaya i predshestvuyuschie arkheologicheskie ekspeditsii. In: Piotrovskiy, M. B (ed.). Ekspeditsii. Arkheologiya v Ermitazhe. Sankt-Peterburg: Slaviya, s. 236-249.

Skoriy, S. A. 1990. Kurgan Perepyatikha. Kiev: Naukova dumka.

Sokrovisha... 1985. Sokrovisha kurganov Adygei. Moskva: Sovetskiy khudozhnik.

Ul'skie... 2015. Ul'skie kurgany. Kul'tovo-pogrebalniy kompleks skifskogo vremeni na Severnom Kavkaze. Moskva: Palegraf.

Trepalov, V. V. 2004. Vozhd' i zhrets v epicheskom folklore tiurko-mongolskikh narodov: nekotorye osobennosti organizatsii traditsionnoj vlasti u kochevnikov. In: Bazarov, B. V., Kradin, K. K. (ed.). Mongol'skaya imperiya $i$ kochevoj mir. Ulan-Ude: BNTs SO RAN, s. 76-100.

Khazanov, A. M. 1975. Sotsial'naya istoriya skifov. Moskva: Nauka.

Erlikh, V. R. 2010. Raskopki kurgana Ul'skoj gruppy v 2007 g. Material'naya kultura vostoka, 5, s. 117-137.

Erlikh, V. R., Nekhaev, A. A. 2011. Kurgany epokhi skifskoj arkhaiki u khutora Goverdovskiy v Adygee. In: Mamaev, Kh. M.(ed.). Voprosy drevney $i$ srednevekovoj arkheologii Kavkaza. Grozniy; Moskva: IA RAN, s. 131-152.

\section{B. Maxopmux}

\section{ДО ПРОБЛЕМИ ВИДІЛЕННЯ ЦЕНТ- РІВ ВЛАДИ У СКІФІВ СХІДНОЇ ЄВ- РОПИ У VII-VI ст. до н. е.}

VII-VI ст. до н. е на півдні Східної Європи пов'язується із появою та активною діяльністю скіфрів. Кочівники брали участь у найважливіших подіях світової історії та контактували із такими провідними державами Передньої Азії як Урарту, Ассирія, Мідія, а також грецьким полісами Північного Причорномор'я. Аналіз скіфрських поховань доби архаїки на півдні Східної Свропи дозволив виокремити кілька груп пам'яток, що локалізуються на Північному Кавказі і у лісостеповому Подніпров'ї, зокрема Центральнокавказьку, Кубанську, Посульсько-Ворсклінську і Киево-Черкаську. 3 цими групами пов'язані скупчення курганів, що включають поховання скіфрської військової еліти, а також великі «царські» кургани, які ідентифрікують центри скіфрської влади і визначають етнокультурну специфіку різних регіонів Східної Свропи у розглянутий період. Скіфрські центри влади VII-VI ст. до н. е мали свої локальні особливості, які визначалися кількістю наявних у їх розпорядженні людських ресурсів, етно-культурним складом, характером взаємин із місцевим населенням та іншими факторами. Центральнокавказьку та Кубанську групи пам'яток слід розглядати у контексті північнокавказького центру влади, який існував протягом VII-VI ст. до н. е. У Подніпров"ї виділяються два центри скіфрської влади. Перший (Киево-Черкаська група пам'яток) розташовувався у лісостеповому Правобережжі, і ймовірно, належав кільком гетерогенним родовим групам. Другий центр у лісостеповому Лівобережжі (ПосульськоВорсклінська група пам'яток) був пов'язаний із більш однорідною і численною групою скіфрького населення, що мешкало тут у період між VII-VI ст. до н. е. та IV ст. до н. е. Нові дослідження дозволять конкретизувати питання про те, на яких засадах існував адміністративнотериторіальний поділ східноевропейської Скіфрії в VIIVI ст до н. е., а також простежити подальшу історичну долю скіфрських племінних утворень, що локалізувалися у цьому регіоні.

Ключові слова: скіфи, центри влади, VII-VI ст. до н. е., Північний Кавказ, лісостепове Подніпров’я.

Одержано 01.07.2019

МАХОРТИХ Сергій Володимирович, доктор історичних наук, провідний науковий співробітник, Iнститут археології НАН України, пр. Героїв Сталінграда, 12, Київ, 04210, Україна.

MAKHORTYKHSergey, Doctor of HistoricalSciences, Chief Research Fellow, Institute of Archaeology, National Academy of Sciences of Ukraine, Heroiv Stalingradu ave., 12, Kyiv, 04210, Ukraine.

ORCID: https://orcid.org/0000-0002-7711-8117, e-mail: makhortykh@yahoo.com. 